\title{
FORECASTING OF DEVELOPMENT TRENDS OF SOCIAL MEDIA MARKETING IN UKRAINE
}

The concept of social media marketing, its main tools and opportunities for using the company to communicate with clients and receive feedback are considered. The necessity of using social media marketing company has been determined, $48 \%$ of consumers increase desire to buy a product of a brand that reacts sensitively to its customers in social media. The rating of the most popular social networks of the world is made. The state of social media marketing in Ukraine, tools of its application is investigated. The most used sites in Ukraine are considered and it is found that the first places in the rating are social networks. Three of the top five most popular sites are social networks. The rating of the most popular social networks in Ukraine is built. It is revealed that for Ukraine, social media marketing is relatively new, since it appeared only a few years ago, but today it has become quite powerful. Recently, there have been even special agencies that provide SMM services to companies. Despite the fact that SMM is only beginning to develop actively in Ukraine, it is worth noting how fast it develops and at what high level it is now. The number of users of social networks is increasing every minute both in the world and in Ukraine, further forecasts predict an even greater increase in interest in social networks in the future. It is revealed that in Ukraine the most popular social network is Facebook (in June 2017, Facebook reached $51.96 \%$ ). Based on the data on the use of social networks by online users, a forecast is made for the development of the five most popular social networks in Ukraine including Facebook, VKontake, YouTube, Instagram, Odnoklassniki. Based on the forecast it is defined that the number of users of such social networks as VKontakte and Odnoklassniki will decrease with time, and Youtube, Facebook, and Instagram will grow steadily.

Keywords: social network; Internet marketing; media marketing; social network user; development forecast.

Relevance of the topic. On average, today, the person spends $116 \mathrm{~min}$. of her/his time for social networks. Now over 5.7 billion profiles are registered worldwide. Every second the number of users of social networks increases by 8 people. Social networks are popular now, more than ever earlier. The activity which is shown by people on social networks strikes: in the most popular projects the average user checks up to hundred pages a day. This is what many years all online projects aspired to, however social networks managed to realize similar to it. Therefore it is very important to companies to use this tool for communication with the existing clients and attraction of new ones.

Analysis of the last sources. The concept Social Media Marketing (SMM) is investigated in works of D. Neyshos, Andreas Kaplan, Michael Hayenleya, I. Bashinskaya, A. Mriglodi, Jonah Bergerda, A. Senatorov, E. Sernovits, D. Kennedy, D. Zarell, V. Kozents, G. Dragon, K. Smith, M. Hayatt, K. Brogan, M. Miller, N. Yermolova, D. Kot, M. Kryuchkova, E. Kuchin and other SMM strategists who disclose essence of a social media marketing concept and the principles of its work. But the number of social networks is constantly growing, there are also new instruments of their work which need further researches.

The purpose of this article is the research of the theory of the SMM concept in Ukraine as one of instruments of company promotion. Due to the goal, the following tasks are highlighted:
- consideration of the SMM concept and its tools;

- the analysis of popularity of social networks in Ukraine;

- researches of SMM tendencies in Ukraine;

- forecasting concerning development of SMM in Ukraine.

Main material. Media Marketing concept is widely used among the marketing specialists, people who are engaged in advertizing and public relation. And it is still unknown to general public.

Social Media Marketing - is literally translated from English as marketing on social networks advance on social networks. It is an internet marketing component that, in turn, became an integral part of traditional marketing.

Internet marketing is the new type of marketing including traditional elements (goods, distribution, promotion, market researches) realized by means of the Internet tools in the remote, interactive mode and therefore providing a possibility of acceleration, reduction in cost and better implementation of all marketing processes (Iliashchenko, 2011).

Internet marketing consists of such tools:

- contextual advertizing;

- search optimization;

- SMO (optimization of the website under social networks), SMM;

- virus marketing;

- media advertizing;

- mailings.

\section{Інформація про авторів:}

Двуліт Зоряна Петрівна, канд. екон. наук, доцент. Email: zdvulit@ukr.net; https://orcid.org/0000-0002-2157-1422

Онищенко Олександра Юріївна, магістр. Email: aleksandra4208118@gmail.com

Цитування за ДСтУ: Двуліт З. П., Онищенко О. Ю. Forecasting of development trends of social media marketing in Ukraine. Науковий вісник НЛТУ України. Серія Економічна. 2018, т. 28, № 4. С. 41-45

Citation APA: Dvulit, Z. P., \& Onyshchenko, O. Yu. (2018). Forecasting of Development Trends of Social Media Marketing in Ukraine. Scientific Bulletin of UNFU, 28(4), 41-45. https://doi.org/10.15421/40280407 
SMM is a website promotion in social services by publications of relevant interesting materials in communities, forums, social networks. It consists in constant communication with users, the embedded advertizing of goods and services. Use of audio - and video of materials is possible.

Lauren Drell defines SMM as a complex of actions for use of social media as channels for the companies promotion and the solution of other business challenges (Lauren, 2011).

The American researcher D. Neyshos defines the concept "social media marketing" as process of introduction of marketing through social networks (Nations, 2016).

Andreas Kaplan and Michael Hayenley define social means of communication ("media") as "group of Internetapplications on this or that base to an ideological and technological basis Web 2.0 that allows users of social networks to create contents ("content")" (Andreas, Kaplan \& Haenlein, 2010).

By D. Zarellu's definition, SMM - a complex of actions directed to promotion, advance and advertizing of services or goods of the company by means of social resources ( $\mathrm{Za}$ rella, 2010).

The first prototype of social networks has appeared in the mid-nineties of the XX century. There were such web tools which use allowed to establish connection between users within one website. At first users united in network for forming and maintenance of business contacts. Later forums on interests have emerged. Some networks were literally the closed clubs, others joyfully opened their doors to everyone interested. With growth of Internet networks and development of tools, more convenient for the unprepared user, number of the people who are actively using the Internet, before the beginning of the new millennium, have considerably increased. Facebook social network, the most popular in the world now, has appeared in 2014.

Confirmation to the fact that social networks take the important place in life of the modern person is the research of the popular websites among the Ukrainian users. The Gemius company has been rating of 20 most popular websites among Ukrainians till August, 2017. The rating describes PC audience of the country according to Gemius Audience, the international research on measurement of Internet audience which Gemius performs in more than 30 countries of the EMEA region (Europe, the Middle East and Africa). The research is directed to studying of quantity and a demographic profile of Internet users and also their behavior in networks. The research is conducted according to ICC/ESOMAR international code (Fig. 1).

The second place in rating is taken by YouTube social network which number of visits is $73 \%$, that is 14.75 million users. Facebook social network has taken the third place in rating. The number of its visits till August, 2017 have made $53 \%$ (10.71 million users). On the fifth place VKontakte social network which number of visits was $33 \%$ that is is 6.67 million users. From 5 most popular websites, 3 are related to social networks.

The coverage of other social networks is much less. But in a case with Instagram it is necessary to consider the fact that only PC users are brought in statistics, whereas Instagram though has the version for the computer, but it is survey and has no many basic functions. Therefore most of users of Instagram use mobile devices and consequently they aren't considered in the above specified data (GemiusAudience, 2017).
Top-20 of Uanet websites

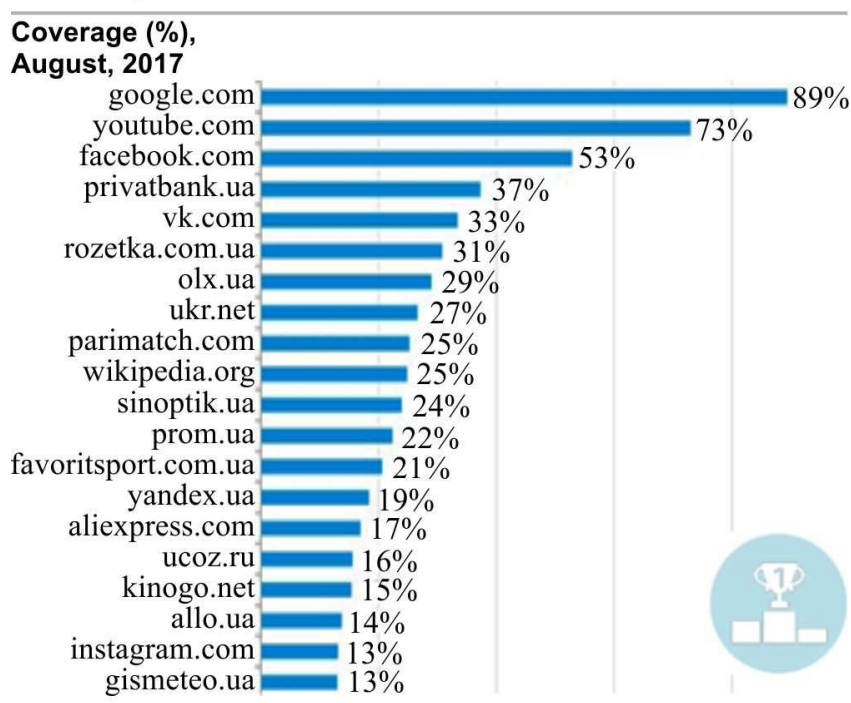

Figure 1. Rating of 20 most popular Uanet websites on attendance

But the tendency of increase in popularity of social networks is observed around the world. Every day new and new social networks emerge. The social media strategist, Vincenzo Cosenza, has created the rating of the most popular social networks in the world (Fig. 2) on the basis of data from Alexa and SimilarWeb (Vincenzo Cosenza, 2017).

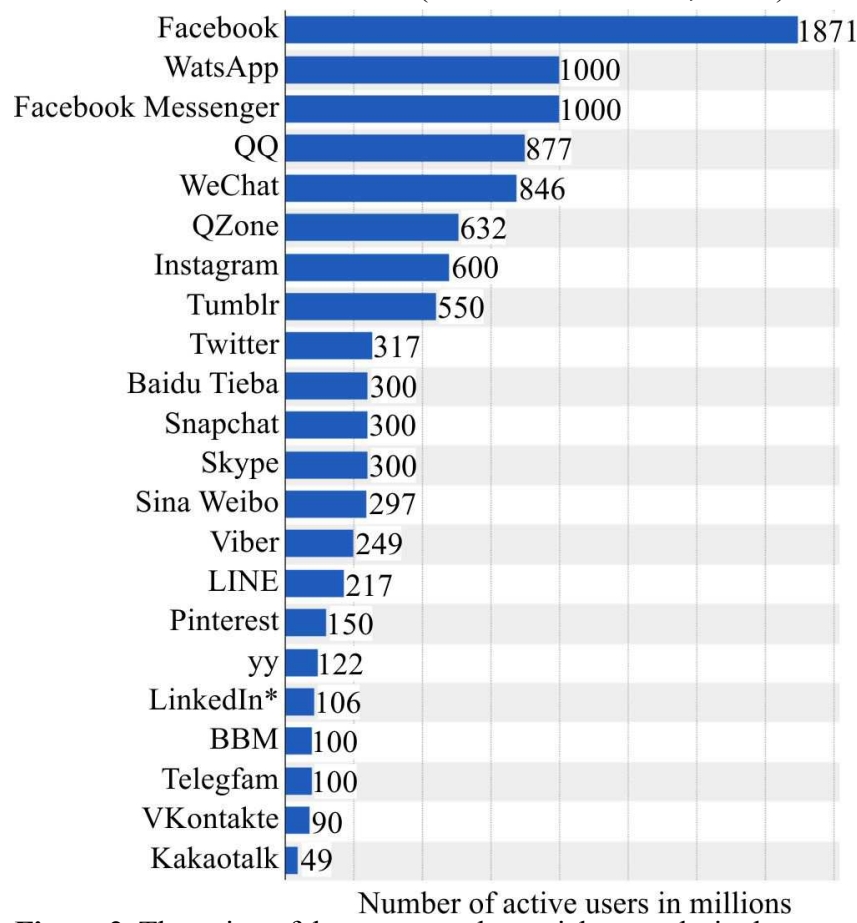

Figure 2. The rating of the most popular social networks in the world

Despite a wide choice of social networks, all of them can differently satisfy various strategic objectives of the company. So, Instagram is widely used for direct sales whereas YouTube or Twitter networks are not good for this purpose. Through Facebook or VKontakte it is convenient to collect feedback. Through Twitter it is convenient to notify on the latest news of the company or to conduct dialogue with target audience.

Social networks are divided into:

- Mass (for any Internet user; communication on any subjects is possible);

- Thematic (orientation on communication is inherent: on interests or professional); 
- Photo - and video hostings (communication through commenting of photos and videos) (Ingate Digital Agency, 2012).

Main areas of SMM work include:

- Creation, design and advance of groups, pages and communities of a brand: Facebook, VKontakte, Twitter and on other social networks;

- Stimulation and increase in interest of audience (holding of open competitions, quizzes and competitions, application creation games and other useful services);

- Creation and distribution of virus newsworthy events (creation of content which quickly extends);

- Analytics (detailed analysis and development of recommendations, constant development of strategy of advance).

Through a variety of social networks first of all it is necessary to choose the purpose of maintaining the social page, and already then the network itself. Tactics of social networks maintaining also will depend on the chosen purpose. A set of means by means of which SMM advance is carried out, is huge. After all implementation of SMM actions is intended to interest not bots, but living people. The main task - to apply tool kit of that social network on which SMM is carried out, because the efficiency of a campaign will be much above.

Despite need of use of various SMM tools for each network, any SMM-campaign includes the following components:

- Definition of target audience and studying of its interests;

- Observation of target audience behavior;

- Carrying out analysis of a client niche;

- Development of the general strategy of work on social networks;

- Selection of tools which solve problems effectively and reliably;

- Integration of SMM activity in the general marketing strategy of the company.

There are known cases when the company held some simple competition about which users of social network wrote on pages for a long time after that, increasing thus recognition of a brand and just creating free advertising for the company. One of such examples - the stock of the IKEA company. For the announcement of new shop opening in Malmö (Sweden), the company used the "Mark Out Yourself on a Photo" function. On the official page of the company 12 photos of different interiors have been published. The user, who the first will note the page on any thing on a photo, receives this thing free of charge. Having noticed itself on a photo, the participant of the action automatically reported about it its friends who saw this news in a news feed. Thus practically all city knew about opening of new shop IKEA.

One of the new latest SMM tools - introduction of chat bots. The New Year's Eve advertising campaign of CocaCola, in which a chat bot have been used on the VKontakte platform, which suggested its interlocutors to receive a festive set of stickers for the photo with a drink bottle, can be examples of such campaigns. "Virtual Johnnie on days off" from the Johnnie Walker company to its 150th anniversary is one more example of the advertising campaign which is carried out with the help of a chat bot. The purpose of a campaign was to popularize drinks among young audience $(21+)$. New communication strategy "Weekends are made for whisky" has been developed. DIEVO was responsible for realization of this campaign in Ukraine. Within the communication platform the agency has suggested to address non-standard tools and to start a personalized chat bot on the basis of Facebook Messenger. The Team301 company has acted as the technical partner.

The main hero of a campaign - Johnnie Walker which communicated in Ukrainian with users. Under the terms of activation, virtual Johnnie appeared online during week-end - from Friday evening and until the end of Sunday within five weeks. Each two hours he asked questions to his interlocutor and if the person answered correctly, then had an opportunity to win a prize. The winner among those who have given the correct answer got out randomly. Competitive questions concerned the most various subjects and have been constructed in a quest format. During 135 tasks the user learned about story which Johnnie Walker told, learned the facts about production and the culture of whisky consumption, guessed the countries where the hero has visited, and even reminded him of his own origin.

The chat bot made active interest in Johnnie Walker. Such company was extremely effective for a brand. Thanks to media support in an advertizing format in Facebook aimed at dialogue in Messenger, the brand has attracted more than 20 thousand users. The average quantity was 27 answers to one participant, content has unambiguously caused desire to continue to communicate with the bot, even in spite of the fact that not every participant could win a prize. Users have been interested as evidenced by indicator of Google Trends, which has grown twice in comparison with last year. Also, thanks to a large number of winners, it was succeeded to create group of the "lawyers of a brand" already loyal to it.

The page of the company on social network is its face. Exactly here it can conduct dialogue with already existing or potential clients. The timeliness, adequacy and compliance with the style of the company belongs to the basic principles of communication of the company with users. The behaviour of a brand influences consumer decisions.

The Sprout Social company has investigated 289000 users in networks and more than 1000 consumers are interviewed. Such analysis has revealed that desire to get a product of a brand which sensitively reacts to the buyers in social media increases at $48 \%$ of respondents. $36 \%$ of respondents have noted that the sense of humour of a brand involves them in purchase. $67 \%$ of respondents have noted what isn't pleasant to them when brands deride their competitors, $10 \%$ of respondents have reported that they would get a product from a brand which enters disputes on social network with its competitors.

According to Sprout Social, the loyalty of consumers to the company decreases when brands deride competitors $(88 \%)$, talk abut politics $(71 \%)$ and use a slang (69\%) (King, Karen, 2015).

Year Dragon, the SMM manager, CEO Dragon Search has highlighted 5 main points which will allow to achieve desirable results through social networks:

- Service of a brand: monitoring of all channels and answers to all questions on the page of the company.

- Maintaining of a page: identification of lawyers of a brand, fans, who like productions/company services.

- Influence distribution: it is necessary to find influential people in the sphere of the company and to do so that they were a conductor of the ideas of the company.

- Management of the project reputation and development of the project.

- Creative campaign which will draw attention to a brand for a certain time. 
In Ukraine the most popular social network - Facebook enjoyed by $43 \%$ of online users use on average. In June, 2017 the indicator of Facebook has reached $51.96 \%$. The rating of social networks among the Ukrainian users is made by the Internet marketing specialist, the head of the UAWEB Internet agency, Anton Yudin on the basis of statistics for a year (June, 2016/June 2017) (Fig. 3) and for June, 2017 (Fig. 4) on gs.statcounter.com. which traces such websites as: Google+, LinkedIn, Facebook, Tumblr, YouTube, Twitter, reddit, Digg, MySpace, NowPublic, mylife, orkut, Fark, Delicious, Stumbleupon, Hi5, Yahoo! Buzz, Vimeo, Mixx, FriendFeed, Hyves, Bebo, Tuenti, Kaboodle, Odnoklassniki (Yudin, 2017).

\begin{tabular}{l} 
Other $0,03 \%$ \\
news.ycombinator.com $0,01 \%$ \\
Fark $0,01 \%$ \\
Stumbleupon $0,12 \%$ \\
Google+ $0,21 \%$ \\
LinkedIn $0,35 \%$ \\
reddit $0,38 \%$ \\
Instagram $0,48 \%$ \\
Tumblr $2,17 \%$ \\
Pinterest $4,88 \%$ \\
Twitter $11,03 \%$ \\
YouTube $13,94 \%$ \\
Vkontakte $22,89 \%$ \\
\hline
\end{tabular}

Figure 3. The rating of the most popular social networks in Ukraine for a year (June, 2016/June 2017)

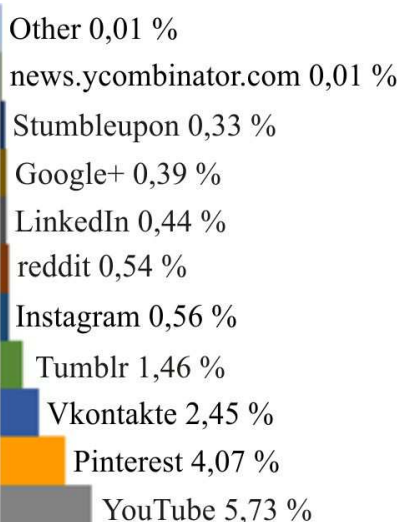

Twitter 32,05\%

Facebook 51,96\%

Figure 4. The rating of the most popular social networks in Ukraine till June, 2017

The leader among social networks is Facebook. The second place was taken by social network VKontakte, but in June, 2017 VKontakte has taken the fifth place. Sharp recession of popularity of VKontakte caused by the ban by the Decree of the President of Ukraine No. 133/2017 "About the decision of the National Security and Defense Council of Ukraine of April 28, 2017 "About application of personal special economic and other restrictive measures (sanctions) of this social network. Because of it there was an increase in users of Facebook social network. In the first week after the ban of the Russian social networks in Ukraine (from 05/18/2017), there was a strong peak in number of new registration.
Change of number of the Ukrainian users of the most popular social networks in Ukraine are presented in graphics "Dynamics of number of users of the most popular social networks in Ukraine till June, 2016 - November, 2017" (Fig. 5) Schedule of coverage of users in percent of 5 most popular social networks: Facebook, VKontake, YouTube, Instagram, Odnoklassniki from June, 2016 to November, 2017 is created on the basis of information from the Factum Group Ukraine and Internet of Association of Ukraine companies.

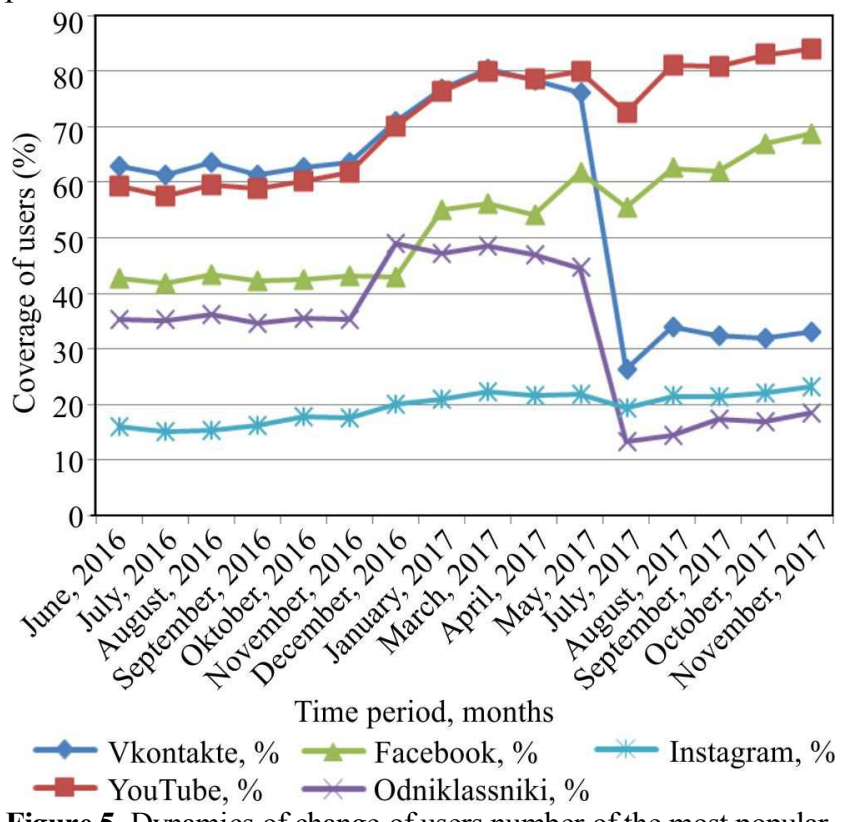

Figure 5. Dynamics of change of users number of the most popular social networks in Ukraine till June, 2016 - November, 2017

Using function of the trend line creation, the forecast for the next 4 months (Tab.) has been made

Table Expected indicators for popular social networks

\begin{tabular}{|c|c|c|c|c|}
\hline $\begin{array}{c}\text { The most popu- } \\
\text { lar social net- } \\
\text { works in Ukra- } \\
\text { ine }\end{array}$ & $\begin{array}{c}\text { December, } \\
2017\end{array}$ & $\begin{array}{c}\text { January, } \\
2018\end{array}$ & $\begin{array}{c}\text { March, } \\
2018\end{array}$ & $\begin{array}{c}\text { April, } \\
2018\end{array}$ \\
\hline YouTube & 86.32 & 88.73 & 89.67 & 91.12 \\
\hline VKontakte & 32.43 & 31.1 & 29.76 & 27.67 \\
\hline Facebook & 71.11 & 72.53 & 75.11 & 77.15 \\
\hline Instagram & 26.13 & 29.14 & 34.98 & 44.56 \\
\hline Odnoklassniki & 17.46 & 16.27 & 15.78 & 13.37 \\
\hline
\end{tabular}

According to the forecast, the indicator of coverage of users of YouTube will be $91.12 \%$ in April, 2018. The reliability of approximation is confirmed with statistics - coefficient of multiple determination $(\mathrm{R} 2=0.8638)$. The number of Facebook's users in April, 2018 will also grow, having reached $77.15 \%$ (coefficient of multiple determination $\mathrm{R} 2=0.8819)$. The coverage of VKontakte social network will be $27.67 \%$ (coefficient of multiple determination $\mathrm{R} 2=0.4177$ ). According to the forecast, the coverage of Instagram social network will grow to $44.56 \%$ (coefficient of multiple determination R2 $=0.9433$ ), and the indicator of coverage of Odnoklassniki social network will decrease to a mark of $13.37 \%$.

According to the data of indicators, growth of social networks not only won't decrease, but also will grow on the contrary. The number of users of such social networks as VKontakte and Odnoklassniki will decrease as time passed, and Youtube, Facebook, Instagram steadily raise.

Conclusions. So, SMM is a process of social networks maintaining by the company. It is carried out for the purpo- 
se of increase in sales, involvement of new clients and maintenance of image of the company. For these purposes both traditional advertizing on open spaces of social networks and the publication of unique and interesting content, interaction with audience can be used.

This subject is still rather new to Ukraine, because SMM has appeared several years ago, but already today it became the powerful instrument of internet marketing. The number of social networks users grows every minute as around the world, and in Ukraine, further forecasts predict a bigger growth of interest in social networks in the future therefore SMM-management is extremely important and necessary for effective work of the company and communication with its clients.

Today, not all enterprises apply advantages of SMM to their development, but more and more enterprises realize importance of use of this tool. Recently there are even special agencies which provide to the companies services in SMM sphere. In spite of the fact that SMM only begins to actively develop in Ukraine, it should be noted that it is powerfully developing, thereby being at the high level of development.

\section{Перелік використаних джерел}

Andreas, M. Kaplan, \& Michael, Haenlein. (2010). Users of the world, unite! The challenges and opportunities of Social Media. Business Horizons, 53, 59-68. https://doi.org/10.1016/j.bushor.2009.09.003

GemiusAudience. (2017). Populiarni saity Uanetu v serpni 2017 ro$k u$. [Uanet Popular sites in August 2017]. Retrieved from: http://www.gemius.com.ua/vse-stati-dlja-chtenija/populjarni-sajtiuanetu-v-serpni-2017-roku.html. [In Ukrainian].

Iliashchenko, S. M. (2011). Suchasni tendentsii zastosuvannia internet-tekhnolohii v marketynhu. [Modern trends in the use of Internet technologies in marketing]. Retrieved from: http://mmi.fem.sumdu.edu.ua/sites/default/files/mmi2011_4_2_64_74.pdf. [In Ukrainian].

Ingate Digital Agency. (2012). Prostoe y nahliadnoe posobye po marketynhovim kommunykatsyiam $v$ sotsyalnikh setiakh. [Simple and intuitive guide to marketing communications in social networks]. Moscow: Ingate. [In Russian].

King, Karen. (2015). Pitney Bowes Study Reveals International Differences of Opinion and Behavior on How Consumers Shop the World. Retrieved from: https://www.businesswire.com/news/home/20151014005361/en/Pitney-Bowes-Study-Reveals-International-Differences-Opinion\#.ViEGm9LhCWh

Lauren, Drell. (2011). How Social Media Is Changing Paid, Earned \& Owned Media. Retrieved from: http://mashable.com/2011/06/23/paid-earned-owned-media/\#3U1DsgIKqSq8

Nations, D. (2016). What is Social Media Marketing? Retrieved from: $\mathrm{http} / /$ webtrends.about.com/od/web20/a/what-is-social-media-marketing.htm

Vincenzo Cosenza. (2017). The world's most popular social networks, mapped. Retrieved from: https://www.weforum.org/agenda/2017/03/most-popular-social-networks-mapped/

Yudin, A. (2017). Naipopuliarnishi sotsialni merezhi v krainakh SND $i$ sviti. [The most popular social networks in the CIS and the world]. Retrieved from: https://marketer.ua/ua/top-social-media-2017/. [In Ukrainian].

Zarella, D. (2010). The social media marketing book. Canada: O'Reilly Media.

Державний університет інфраструктури та технологій, м. Київ, Україна

\section{ПРОГНОЗУВАННЯ ТЕНДЕНЦІЙ РОЗВИТКУ СОЦІАЛЬНОГО МЕДІАМАРКЕТИНГУ В УКРАЇНІ}

Розглянуто поняття "соціальний медіамаркетинг", основні його інструменти та можливості використання компанією для спілкування із клієнтами та отримання зворотного зв'язку. Складено рейтинг найпопулярніших соціальних мереж світу. Досліджено стан соціального медіамаркетингу в Україні, інструментів його застосування. Побудовано рейтинг найпопулярніших соціальних мереж в Україні. З'ясовано, що для України соціальний медіамаркетинг відносно новий, адже з'явився тільки декілька років тому, але вже сьогодні він став дуже потужним. Кількість користувачів соціальних мереж щохвилини зростає, як у всьому світі, так і в Україні, подальші прогнози передбачають ще більше зростання інтересу до соціальних мереж у майбутньому. Встановлено, що в Україні найпопулярніша соціальна мережа - Facebook (у червні 2017 p. показник Facebook досяг 51,96 \%). На основі даних використання соціальних мереж онлайн-користувачами складено прогноз розвитку 5 найпопулярніших соціальних мереж в Україні: Facebook, VKontake, YouTube, Instagram, Odnoklassniki. На основі прогнозу виявлено, що кількість користувачів таких соціальних мереж, як VKontakte та Odnoklassniki, з часом буде зменшуватися, а Youtube, Facebook, Instagram - стабільно зростати.

Ключові слова: соціальна мережа; інтернет-маркетинг; медіамаркетинг; користувач соціальної мережі; прогноз розвитку.

3. П. Двулит, О. Ю. Онищенко

Государственный университет инфраструктуры и технологий, г. Киев, Украина

\section{ПРОГНОЗИРОВАНИЕ ТЕНДЕНЦИЙ РАЗВИТИЯ СОЦИАЛЬНОГО МЕДИАМАРКЕТИНГА В УКРАИНЕ}

Рассмотрено понятие "социальный медиамаркетинг", основные его инструменты и возможности использования компанией для общения с клиентами и получения обратной связи. Составлен рейтинг самых популярных социальных сетей мира. Исследовано состояние социального медиамаркетинга в Украине, инструментов его применения. Построен рейтинг самых популярных социальных сетей в Украине. Выяснено, что для Украины социальный медиамаркетинг является относительно новым, ведь появился лишь несколько лет назад, но уже сегодня он стал очень мощным. Количество пользователей социальных сетей ежеминутно растет, как во всем мире, так и в Украине, дальнейшие прогнозы предусматривают еще больший рост интереса к социальным сетям в будущем. Установлено, что в Украине самая популярная социальная сеть - Facebook (в июне 2017 г. показатель Facebook достиг 51,96 \%). На основе данных использования социальных сетей онлайн-пользователями составлен прогноз развития 5 самых популярных социальных сетей в Украине: Facebook, VKontake, YouTube, Instagram, Odnoklassniki. На основе прогноза установлено, что количество пользователей таких социальных сетей, как VКontakte и Odnoklassniki, со временем будет уменьшаться, a Youtube, Facebook, Instagram - стабильно расти.

Ключевые слова: социальная сеть; интернет-маркетинг, медиамаркетинг, пользователь социальной сети, прогноз развития.

Науковий вісник НЛТУ України, 2018, т. 28, № 4 Scientific Bulletin of UNFU, 2018, vol. 28, no 4 